\title{
EFEK KONSELING TERHADAP TINGKAT PENGETAHUAN IBU PADA TERAPI DIARE BALITA
}

\author{
Counseling Effect On Mother Knowledge In Diarrhea Therapy For Young Child \\ Khaerani $^{1}$, Surya Ningsi ${ }^{2}$, Andi Try Resti Fauziah Sahib ${ }^{2}$ \\ ${ }^{1}$ Stikes Salewangang Maros \\ ${ }^{2}$ Universitas Islam Negeri Alauddin Makassar \\ Email korespondesi / No.hp : chaeranhie@gmail.com / 085255912413
}

\section{https://doi.org/10.32382/mf.v14i2.561}

\begin{abstract}
The role of pharmacists in optimizing diarrhea therapy in patients is needed where pharmacists are expected to provide counseling about the right therapy for child diarrhea. Counseling is a component of pharmaceutical services that needs to be implemented to improve therapeutic outcomes, by maximizing the use of drugs. This study aims to determine whether there is a counseling effect on maternal knowledge in the treatment of diarrhea for their child in Puskesmas Pampang district Makassar. This research is a non-experimental study with observational analytic research design using quantitative analysis and study design of one group pre-post test study. Data were collected using questionnaires. The results showed that there were differences in the level of meaningful knowledge between the results of the pre-test and post-test where the significance data of the two groups of data was $0.000(p<0.05)$ which stated that there was a counseling effect on maternal knowledge on diarrhea diarrhea therapy in Puskesmas Pampang.
\end{abstract}

\section{ABSTRAK}

Peranan farmasis dalam mengoptimalkan terapi diare pada pasien sangat dibutuhkan dimana farmasis diharapkan dapat memberikan konseling tentang terapi yang benar pada diare anak. Konseling merupakan komponen dari pelayanan kefarmasian yang perlu dilaksanakan untuk meningkatkan hasil terapi, dengan memaksimalkan penggunaan obat yang tepat. Penelitian ini bertujuan untuk mengetahui apakah terdapat hubungan konseling terhadap tingkat pengetahuan ibu di Puskesmas Pampang kota Makassar dalam terapi diare pada balita. Penelitian ini merupakan penelitian non eksperimental dengan rancangan penelitian analitik observasional dengan menggunakan analisis kuantitatif. Pendekatan waktu yang digunakan yaitu rancangan penelitian observasional studi one group pre-post test. Data dikumpulkan menggunakan kuesioner yang kemudian dianalisis menggunakan SPSS. Hasil penelitian menunjukkan bahwa terdapat perbedaan tingkat pengetahuan yang bermakna antara hasil pre-test dengan post-test dimana data significancy dari kedua kelompok data adalah $0,000(p<0,05)$ yang menyatakan bahwa adanya hubungan konseling terhadap tingkat pengetahuan ibu pada terapi diare balita di Puskesmas Pampang kota Makassar.

Kata kunci: Diare, Konseling, Pengetahuan

\section{PENDAHULUAN}

Kesehatan menurut Organisasi Kesehatan Sedunia (WHO) tahun 2010 merupakan keadaan seimbang dari kesehatan jasmani, mental/rohani dan sosial dan tidak hanya semata terbebas dari penyakit dan kecacatan. Sehat adalah sebuah investasi, aset, dan harta yang paling berharga bagi setiap individu. Menurut Undang-Undang Kesehatan Nomor 36 Tahun 2009 Kesehatan merupakan hak asasi manusia dan salah satu unsur kesejahteraan yang harus diwujudkan sesuai dengan cita-cita bangsa Indonesia sebagaimana dimaksud dalam pancasila dan Undang-Undang Dasar Republik Indonesia Tahun 1945.

Diare menjadi penyebab kedua kematian balita di dunia. Berdasarkan hasil riset kesehatan dasar menunjukkan bahwa insiden diare pada kelompok usia balita di Indonesia adalah 10,2 \% . Lima provinsi dengan insiden diare tertinggi adalah Aceh, Papua, DKI Jakarta, Sulawesi Selatan dan Banten (RISKESDAS, 2013: 9).

Penyakit diare masih merupakan masalah kesehatan masyarakat di negara berkembang seperti di Indonesia, Hal ini disebabkan oleh beberapa faktor yakni fasilitas 
kesehatan di negara berkembang yang masih kurang, kurangnya air bersih, infrastruktur kesehatan yang masih kurang memadai, BAB tidak pada tempatnya, tidak adanya sarana jamban yang baik, lingkungan yang kurang bersih dan para orang tua yang tidak mengetahui cara mengatasi dehidrasi. Survei morbiditas yang dilakukan oleh Subdit Diare, Departemen Kesehatan dari tahun 2000 s/d 2010 terlihat kecenderungan insidens naik. Pada tahun 2000 IR penyakit Diare 301/ 1000 penduduk, tahun 2003 naik menjadi $374 / 1000$ penduduk, tahun 2006 naik menjadi 423 /1000 penduduk dan tahun 2010 menjadi 411/1000 penduduk. Kejadian Luar Biasa (KLB) diare juga masih sering terjadi, dengan CFR yang masih tinggi. Pada tahun 2008 terjadi KLB di 69 Kecamatan dengan jumlah kasus 8133 orang, kematian 239 orang (CFR 2,94\%). Tahun 2009 terjadi KLB di 24 Kecamatan dengan jumlah kasus 5.756 orang, dengan kematian 100 orang (CFR 1,74\%), sedangkan tahun 2010 terjadi KLB diare di 33 kecamatan dengan jumlah penderita 4204 dengan kematian 73 orang (CFR 1,74\%.) (Kementerian Kesehatan RI, 2015: 147).

Berdasarkan data dari Dinas Kesehatan kota makassar menunjukkan bahwa angka kejadian diare tertinggi pada tahun 2015 dikota makassar adalah kecamatan Panakkukang yaitu sebanyak 4360 jiwa. Data Dinas Kesehatan kota makassar juga menunjukkan bahwa puskesmas yang memiliki persentase tertinggi pada tahun 2015 terkait kasus diare adalah Puskesmas Pampang yaitu sebanyak 1950 jiwa. Situasi kasus diare berdasarkan penggolongan umur kota Makassar pada tahun 2015 bahwa pada umur $\geq 5$ tahun sebanyak 14746 jiwa, selanjutnya pada umur 1 - 4 tahun sebanyak 10096 jiwa dan pada umur 0$<1$ tahun sebanyak 1415 jiwa. Puskesmas pampang sebelumnya berturut - turut yakni pada tahun 2013 hingga 2014 menempati urutan ke lima terkait kasus diare namun akhirnya meningkat drastis pada tahun 2015 dan menempati urutan pertama diantara seluruh puskesmas di kota Makassar.

Salah satu peran farmasis dalam mengurangi resiko penyakit diare adalah Pelayanan kefarmasian. Pelayanan kefarmasian adalah penyedia pelayanan yang langsung bertanggung jawab terkait dengan obat, dengan maksud pencapaian hasil yang pasti dan meningkatkan mutu kehidupan pasien (PP 51, 2009).

Pelayanan kefarmasian merupakan suatu pelaksanaan yang fungsinya terorganisir, terstruktur meliputi pelayanan langsung seharihari yang tidak dapat dipisahkan dai sistem pelayanan kesehatan yang ada dilaksanakan secara utuh dan lebih fokus atau berorientasi kepada pasien dalam hal penyembuhan pasien juga dalam penyediaan obat yang aman dan efektif serta harga obat yang terjangkau oleh semua lapisan masyarakat yang berstatus pasien (Rikomah, 2016: 30).

Konseling adalah diskusi, nasehat, edukasi tentang penyakit dan pengobatan sehingga pasien memperoleh keuntungan yang optimal dalam meningkatkan kualitas hidup dan perawatannya. Konseling merupakan komponen dari pelayanan kefarmasian yang perlu dilaksanakan untuk meningkatkan hasil terapi, dengan memaksimalkan penggunaan obat yang tepat (Rikomah, 2016: 44).

Pengetahuan pasien yang baik setelah diberikan konseling merupakan salah satu tujuan yang ingin dicapai oleh farmasis. Diketahui bahwa setiap individu memiliki tingkat pengetahuan yang berbeda-beda sehingga ini menjadi salah satu tugas utama seorang farmasis untuk memberikan konseling dengan sebaikbaiknya agar pasien dapat lebih memahami dan tidak adanya lagi kesalahan dalam penanganan terapinya.

Pengetahuan ibu sangat berpengaruh dalam penatalaksanaan diare dirumah. Karena bila pengetahuannya baik maka ibu akan mengetahui tentang cara merawat anak sakit diare dirumah, terutama tentang upaya rehidrasi oral dan juga ibu akan mengetahui tentang tanda-tanda untuk membawa anak berobat atau merujuk ke sarana kesehatan. Tindakan pengobatan yang dilakukan di rumah adalah titik tolak keberhasilan pengelolaan penderita tanpa dehidrasi, juga tindakan untuk mendorong ibu memberikan pengobatan secepat mungkin ketika diare baru mulai. Bila ibu mengetahui prinsip pengelolaan efektif diare, misalnya bila ibu memberikan pengobatan cairan secara oral pada anak di rumah segera setelah anak menderita diare, ini dapat mencegah terjadinya dehidrasi atau mengurangi beratnya dehidrasi (Ariani, Ayu Putri. 2016: 122).

\section{METODE}

Penelitian ini merupakan jenis penelitian non eksperimental dengan rancangan penelitian analitik observasional menggunakan analisis kuantitatif. Pendekatan penelitian yaitu dengan rancangan penelitian observasional studi one group pre-post test. Teknik pengambilan sampel dalam penelitian ini adalah Non probability sampling dengan menggunakan metode Consecutive sampling

\section{HASIL}

Hasil dapat dilihat pada tabel di bawah 


\section{PEMBAHASAN}

Diare adalah buang air besar (BAB) encer atau bahkan dapat berupa air saja (mencret) biasanya lebih dari 3 kali dalam sehari. Diare terdiri dari diare akut, diare persisten dan diare kronik. Diare akut adalah BAB dengan frekuensi yang meningkat dan konsistensi tinja yang lembek atau cair dan bersifat mendadak datangnya dan berlangsung dalam waktu $<2$ minggu. Diare persisten adalah diare akut dengan atau tanpa disertai darah dan berlanjut sampai 14 hari atau lebih. Diare kronik adalah diare yang berlangsung $>4$ minggu (Ariani, Ayu Putri. 2016: 12). Adapun jenis diare yang di alami oleh balita di Puskesmas Pampang kota Makassar tidak diketahui karena pihak puskesmas tidak mengkategorikan secara spesifik jenis diare yang di alami oleh pasien.

Konseling pasien dapat didefinisikan sebagai penyedia informasi, saran atau nasehat tentang obat baik dalam bentuk oral atau tertulis kepada pasien atau yang mewakili mengenai efek samping, penyimpanan, diet dan perubahan gaya hidup. Konseling tidak hanya meningkatkan kepatuhan, tetapi juga terhadap pengobatan. Kepatuhan tidak hanya di pengaruhi dari faktor pasien saja, melainkan juga dipengaruhi oleh tenaga kesehatan yang tersedia, pemberian pengobatan yang komplek, sistem akses dan pelayanan kesehatan (Rikomah, 2016: 45).

Pengukuran pengetahuan dapat dilakukan dengan wawancara atau angket yang menanyakan tentang isi materi yang akan diukur dari subjek penelitian atau responden (Notoatmodjo, 2010: 17).

Adapun perbandingan hasil dari penelitian sebelumnya (Setiabudi, Felicia Marsella. 2015) tentang pengaruh edukasi terhadap pengetahuan ibu-ibu di kecamatan Patrang dalam penanganan diare pada balita dimana penelitian ini menggunakan media leaflet untuk mengukur tingkat pengetahuan ibu pada penanganan diare pada balita sedangkan pada penelitian ini mengukur tingkat pengetahuan ibu melalui konseling kefarmasian oleh apoteker.

Dalam penelitian ini digunakan angket atau kuesioner untuk mengukur tingkat pengetahuan ibu setelah diberikan konseling. Kuesioner yang digunakan terdiri dari pre-test dan post-test. Konseling diberikan setelah pemberian pre-test dan peneliti akan kembali memberikan post-test setelah 10 hari kedepan untuk mengukur atau mengevaluasi pengetahuan pasien. Dalam hal ini evaluasi dilakukan setelah 10 hari dengan alasan yaitu merujuk kepada penggunaan terapi standar yakni penggunaan zinc untuk diare.
Hasil distribusi karakteristik responden menunjukkan bahwa kelompok usia responden terbanyak adalah usia 31-35 tahun (43,3 \%) dan kelompok yang paling sedikit adalah usia $15-20$ tahun sebanyak 3,3\%. Karakteristik responden berdasarkan usia anak menunjukkan kelompok usia anak tertinggi yang mengalami diare adalah usia $2-3$ tahun $(36,7 \%)$ dan kelompok usia anak paling sedikit mengalami diare adalah usia $3-4$ tahun sebanyak $6,7 \%$. Tingkat pendidikan terakhir responden yang paling banyak adalah SMP $(30 \%)$, SD $(26,7 \%)$, SMA/SMK $(26, \%)$, Perguruan tinggi $(16,7 \%)$ dan kelompok yang paling sedikit adalah tidak tamat SD yaitu $0 \%$. Faktor pendidikan merupakan salah satu faktor yang menentukan pengetahuan seseorang. Pendidikan mempengaruhi proses belajar, makin tinggi pendidikan seseorang makin mudah untuk menerima informasi. Dengan pendidikan tinggi maka seseorang akan cenderung untuk mendapatkan informasi, baik dari orang lain maupun dari media massa (Ariani, Ayu Putri, 2016: 121). Pada karakteristik pekerjaan responden terbanyak tidak/belum bekerja yaitu dengan persentase 93,3 \%, jenis pekerjaan umumnya berkaitan dengan tingkat pendidikan dan pendapatan atau sosial ekonomi. Sosial ekonomi mempunyai pengaruh langsung terhadap faktor-faktor penyebab diare. Kebanyakan anak yang mudah menderita diare berasal dari keluarga besar dengan daya beli yang rendah, kondisi rumah yang kurang bailk, tidak mempunyai penyediaan air bersih yang memenuhi syarat dan tidak adanya kamar mandi atau jamban sehat. Status sosial ekonomi yang rendah akan mempengaruhi status gizi anggota keluarga. Hal ini nampak dari ketidakmampuan ekonomi keluarga untuk memenuhi kebutuhan gizi keluarga khususnya pada anak balita sehingga mereka cenderung memiliki status gizi kurang bahkan status gizi buruk yang memudahkan balita tersebut terkena diare. Mereka yang berstatus ekonomi rendah biasanya tinggal di daerah yang tidak memenuhi syarat kesehatan sehingga memudahkan seseorang untuk terkena diare.

Berdasarkan hasil distribusi frekuensi responden dalam menangani diare menunjukkan bahwa banyaknya reponden yang memilih membawa keluarganya ke sarana kesahatan yakni sebanyak $90 \%$ yang dalam hal ini adalah puskesmas. Oleh karena itu perlu adanya pelayanan yang lebih baik oleh tenaga kesehatan salah satunya adalah dengan melakukan konseling terhadap pasien atau keluarga pasien agar mereka dapat mengetahui cara tepat dalam pengananan obatnya serta hal-hal apa saja yang harus dilakukan untuk mendukung dalam proses penyembuhannya. 
Hasil distribusi penggunaan obat diare menunjukkan bahwa sebanyak $60 \%$ ibu memilih untuk tidak mengobati balita namun memilih untuk langsung membawa anaknya ke sarana kesehatan. Adapun obat yang paling banyak digunakan oleh ibu-ibu untuk penanganan awal di rumah adalah oralit yaitu sebanyak $30 \%$. Oralit merupakan pengganti cairan tubuh yang digunakan sebagai alternatif pertama untuk menangani diare. Selanjutnya obat yang biasa digunakan oleh ibu adalah probiotik. Probiotik digunakan untuk mengembalikan keseimbangan flora normal usus dan menghambat pertummbuhan organisme patogen pada saluran cerna, serta mengurangi keadaan intoleransi laktosa. Bakteri probiotik dapat dipakai sebagai cara untuk pencegahan dan pengobatan diare baik yang disebabkan rotavirus maupun mikroorganisme lain, maupun diare yang disebabkan oleh karena pemakaian antibiotika yang tidak rasional (Subijanto, dkk. 2010: 21). Pengobatan selanjutnya yang digunakan ibu adalah dengan pemberian zinc. Tablet zinc berguna untuk mengurangi lama dan tingkat keparahan diare, mengurangi volume tinja dan menurunkan kekambuhan diare pada tiga bulan berikutnya. Zinc merupakan salah satu zat gizi mikro yang penting untuk kesehatan dan pertumbuhan anak. Zinc yang ada dalam tubuh akan menurun dalam jumlah besar ketika anak mengalami diare. Pemberian zinc mampu menggantikan kandungan zinc alami tubuh yang hilang tersebut dan mempercepat kandungan zinc alami tubuh yang hilang tersebut dan mempercepat penyembuhan diare. Kemampuan zinc untuk mencegah diare terkait dengan kemampuannya meningkatkan sistem kekebalan tubuh. Zinc merupakan mineral penting bagi tubuh. Penggunaan suplemen zinc pada balita yang mengalami diare masih sangat rendah yaitu hanya sebesar $6,7 \%$ dari 30 responden. Padahal penggunaan suplemen zinc perlu ditingkatkan guna mengurangi angka kejadian diare pada balita. Masyarakat kemungkinan masih kurang memahami akan kegunaan dari suplemen zinc yang digunakan sebagai pelengkap untuk pengobatan diare pada balita. Dalam hal ini menjadi tugas tenaga kesehatan yaitu apoteker sebagai pelayanan kefarmasian untuk menjelaskan kegunaan dan cara penggunaan zinc yang tepat kepada pasien yakni dengan melakukan konseling. Dimana pemberian pada balita yang menderita diare tetap dilakukan selama 10 hari meskipun diare sudah sembuh. Hal ini ditujukan untuk mengganti zinc yang hilang dari tubuh dan dapat digunakan untuk mencegah terjadinya diare kembali selama tiga bulan berikutnya (Perangin-angin. 2014: 13).
Dalam penelitian ini dilakukan konseling tentang penggunaan obat diare yang baik dan benar. Konseling dilaksanakan oleh apoteker dengan tujuan untuk memberikan pengetahuan kepada pasien tentang penggunaan obat yang baik dan benar, meningkatkan kepatuhan pasien dan untuk mengoptimalkan efek terapi. Dalam hal ini terapi standar puskesmas untuk obat diare adalah oralit dan zinc.

Hasil pre-test pada kuesioner menunjukkan bahwa pernyataan yang paling banyak tidak diketahui oleh sang ibu adalah pernyataan ke 15 . Dimana rata-rata ibu menjawab benar bahwa anak dibawah 5 tahun yang mengalami diare boleh diberi obat antibiotik padahal jawaban yang sebenarnya adalah salah yakni anak dibawah 5 tahun yang mengalami diare tidak boleh langsung diberikan antibiotik namun sebaiknya digunakan oralit dahulu sebagai lini pertama untuk dehidrasi dan pemberian zinc. Menurut ibu jawaban benar di berikan berdasarkan pengalaman yang dialami biasanya pada saat mendapatkan obat untuk anaknya yang menderita diare. Dalam hal ini menjadi peran farmasis dalam memperhatikan kembali peresepan obat yang diberikan kepada pasien utamanya anak balita terlebih dalam pemberian antibiotik. Menurut Departemen Kesehatan RI tahun 2011 antibiotik hanya diberikan sesuai indikasi seperti disentri, kolera dll. Sehingga dalam hal ini pemberian antibiotik pada anak sebaiknya tidak diberikan. Hasil post test menunjukkan bahwa terjadi peningkatan pengetahuan pada ibu, dimana semua ibu menunjukkan nilai post test yang lebih besar dibandingkan nilai pre test.

Berdasarkan uji statistik menunjukkan bahwa terdapat perbedaan tingkat pengetahuan yang bermakna antara hasil pre-test sebelum diberikan konseling dengan post-test setelah diberikan konseling. Hal ini menyatakan bahwa konseling dapat memberikan efek positif pada tingkat pengetahuan pasien sehingga konseling dapat menjadi salah satu hal yang penting yang harus di lakukan oleh tenaga kesehatan yakni farmasis agar membantu dalam mencapai efek terapi yang diharapkan terutama dalam pelayanan kesehatan mulai dari posyandu, puskesmas sampai rumah sakit dimana ada pemberian obat yang harus disertai dengan pemberian konseling untuk meningkatkan kepatuhan dan keberhasilan terapi pasien.

\section{KESIMPULAN}

Dari hasil penelitian yang telah dilakukan dapat disimpulkan bahwa ada hubungan konseling terhadap tingkat pengetahuan ibu pada terapi diare balita di Puskesmas 
Pampang kota Makassar hal tersebut dibuktikan melalui data statistik uji Wilcoxon signed rank test dengan nilai significancy dari kedua kelompok data pre-test dan post-test yaitu p-value $<0,05$.

\section{DAFTAR PUSTAKA}

Ariani, Ayu Putri. 2016. Diare: Pencegahan dan Pengobatannya. Yogyakarta: Nuha Medika.

Depkes RI. 2011. Lintas Diare. Jakarta: Departemen Kesehatan RI Direktorat jenderal Pengendalian Penyakit dan Penyehatan Lingkungan.

Depkes RI. 2007. Pedoman Konseling Pelayanan Kefarmasian Di Sarana Kesehatan. Jakarta: Departemen Kesehatan RI Direktorat Bina Farmasi Komunitas dan Klinik.

Depkes RI. 2009. Sistem Kesehatan Nasional. Jakarta: Departemen Kesehatan RI.

Hair, J.F, et. al. 2010. Multivariate Data Analysis with Reading 4rd Edition. New Jersey: Prentice Hall Internationa.

Kementerian Kesehatan RI. 2014. Infodatin: Kondisi Pencapaian Program Kesehatan Anak Indonesia. Jakarta: Kementerian Kesehatan Republik Indonesia.

Kementerian Kesehatan RI. 2011. Panduan Sosialisasi Tatalaksana Diare Balita. Jakarta: Kementerian Kesehatan Republik Indonesia.

Kementerian Kesehatan RI. 2013. Riset Kesehatan Dasar. Jakarta: Kementerian Kesehatan Republik Indonesia.

Kementrian Kesehatan RI. 2015. Situasi Diare di Indonesia. Jakarta: Kementerian Kesehatan Republik Indonesia

Rikomah, Setya Enti. 2016. Farmasi Klinik. Yogyakarta: Deepublish.

Setiabudi, Felicia Marsella. 2015. Pengaruh edukasi terhadap pengetahuan ibu-ibu dikecamatan patrang dalam penanganan diare pada balita. Fakultas Farmasi Universitas Jember.

Siswanto, dkk. 2015. Metodologi Penelitian Kesehatan dan Kedokteran. Yogyakarta: Bursa Ilmu. 
Tabel01

Distribusi nilai uji validitas kuesioner

\begin{tabular}{cccc}
\hline Item & rhitung & rtabel & Ket \\
\hline Pernyataan & & & \\
\hline P 1 & 0,479 & 0.361 & Valid \\
P 2 & 0,574 & 0.361 & Valid \\
P 3 & 0,456 & 0.361 & Valid \\
P 5 & 0,481 & 0.361 & Valid \\
P 6 & 0,712 & 0.361 & Valid \\
P 7 & 0,481 & 0.361 & Valid \\
P 8 & 0,712 & 0.361 & Valid \\
P 9 & 0,471 & 0.361 & Valid \\
P 10 & 0,531 & 0.361 & Valid \\
P 1 1 & 0,361 & Valid \\
P 12 & 0,694 & 0.361 & Valid \\
P 13 & 0,663 & 0.361 & Valid \\
P 14 & 0,452 & 0.361 & Valid \\
P 15 & 0,557 & 0.361 & Valid \\
P 16 & 0,494 & 0.361 & Valid \\
P 17 & 0,452 & 0.361 & Valid \\
P 18 & 0,611 & 0.361 & Valid \\
P 19 & 0,387 & 0.361 & Valid \\
P 20 & 0,475 & 0.361 & Valid \\
\hline
\end{tabular}

Tabel 02

Distribusi nilai reliabilitas angket variabel bukti fisik

\begin{tabular}{c|c}
\hline \multicolumn{2}{c}{ Reliability Statistics } \\
\hline $\begin{array}{c}\text { Cronbach's } \\
\text { Alpha }\end{array}$ & N of Items \\
\hline .796 & 20 \\
\hline
\end{tabular}

Tabel 03

Karakteristik Responden

\begin{tabular}{lcc}
\hline Karakteristik & $\begin{array}{c}\mathbf{N} \\
\text { (total=100) }\end{array}$ & $\mathbf{\%}$ \\
\hline Usia & & \\
Responden & 1 & 3,3 \\
(tahun) & 5 & 16,7 \\
$16-20$ & 6 & 20 \\
$21-25$ & 13 & 43,3 \\
$26-30$ & 5 & 16,7 \\
$31-35$ & & \\
$>35$ & & \\
& 6 & 20 \\
Usia Anak & 8 & 26,7 \\
(tahun) & 11 & 36,7 \\
$0-1$ & 2 & 6,7 \\
$1-2$ & 3 & 10 \\
$2-3$ & & \\
$3-4$ & & \\
$4-5$ & - & - \\
& 8 & 26,7 \\
Tingkat & 9 & 30 \\
Pendidikan & 8 & 26,7 \\
Tidak tamat SD & 5 & 16,7 \\
\hline
\end{tabular}

\begin{tabular}{lcc} 
SD & & \\
SMP & & \\
SMA/SMK & 28 & 93,3 \\
Perguruan & 2 & 6,7 \\
Tinggi & - & - \\
& - & - \\
Pekerjaan & & \\
Tidak/Belum & & \\
Bekerja & \\
Karyawan & & \\
Guru & \\
Pegawai Negeri & & \\
\hline
\end{tabular}

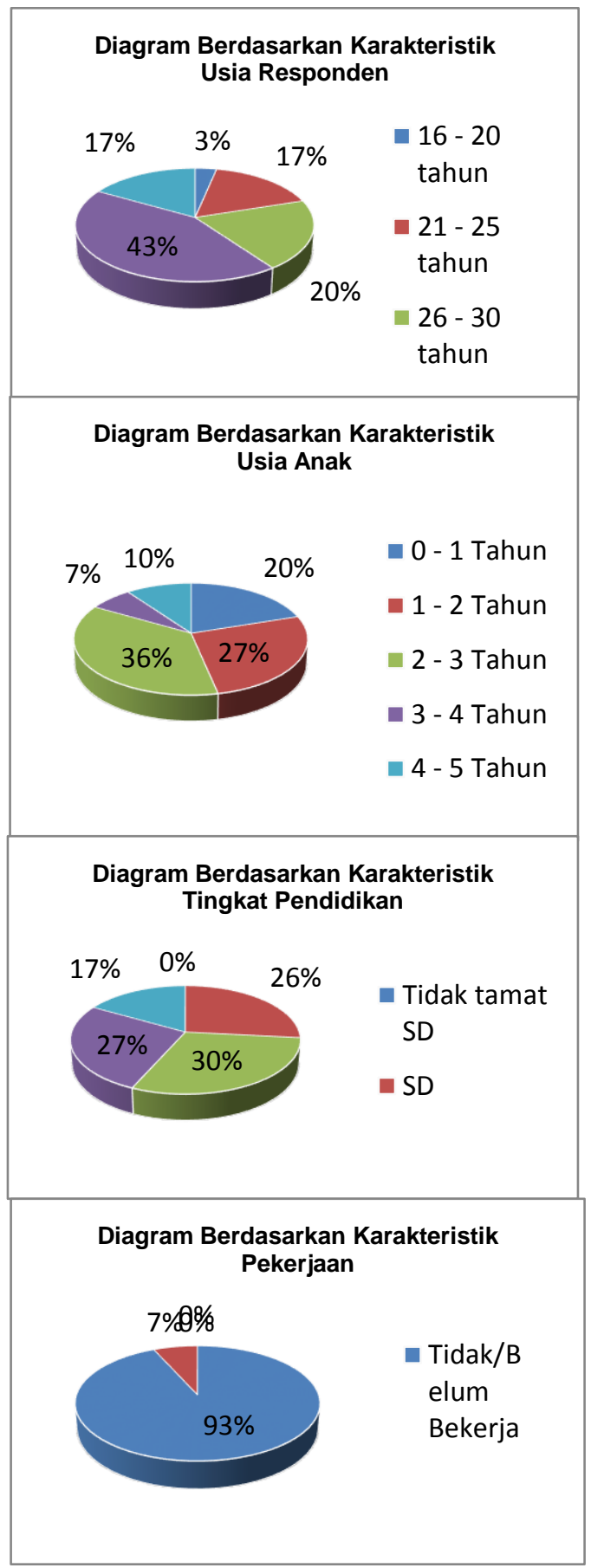


Tabel 04

Distribusi frekuensi responden berdasarkan penanganan diare

\begin{tabular}{lcc}
\multicolumn{3}{c}{ penanganan diare } \\
\hline $\begin{array}{l}\text { Jenis } \\
\text { Penanganan }\end{array}$ & $\mathbf{N}$ & $\mathbf{\%}$ \\
\hline $\begin{array}{l}\text { Diobati } \\
\text { sendiri }\end{array}$ & 1 & 3,3 \\
$\begin{array}{l}\text { Tidak diobati } \\
\text { Sarana }\end{array}$ & - & - \\
$\begin{array}{l}\text { Kesehatan } \\
\text { Menggunakan }\end{array}$ & 27 & 90 \\
$\begin{array}{l}\text { ramuan } \\
\text { tradisional }\end{array}$ & 30 & 6,7 \\
Jumlah & & 100 \\
\hline
\end{tabular}

Tabel 05

Distribusi penggunaan obat diare pada balita

\begin{tabular}{lcc}
\multicolumn{1}{c}{ Nama Obat } & N & \% \\
\hline Tidak & 18 & 60 \\
mengobati & & \\
probiotik & 1 & 3,3 \\
oralit & 9 & 30 \\
zinc & 2 & 6,7 \\
Jumlah & 30 & 100 \\
\hline
\end{tabular}

Tabel 06

Distribusi Persentasi Pengetahuan Ibu

\begin{tabular}{cccc}
\hline Responden & $\begin{array}{c}\text { Nilai } \\
\text { Pre } \\
\text { test }\end{array}$ & $\begin{array}{c}\text { Nilai } \\
\text { Post } \\
\text { test }\end{array}$ & $\begin{array}{c}\text { Perubahan } \\
\text { Skor } \\
\text { Pengetahuan } \\
(\%)\end{array}$ \\
\hline 1 & 18 & 20 & 6,6 \\
2 & 15 & 20 & 16,6 \\
3 & 17 & 20 & 10 \\
4 & 16 & 19 & 10 \\
5 & 16 & 20 & 13,3 \\
6 & 11 & 20 & 30 \\
7 & 14 & 19 & 16,6 \\
8 & 17 & 20 & 10
\end{tabular}

13,3

3,3

43,3

10

3,3

36,6

13,3

10

16,6

6,6

3,3

13,3

13,3

40

13,3

3,3

26,6

13,3

40

13,3

6,6

10




Tabel 07

Distribusi Frekuensi Hasil Pengisian Kuesioner

\begin{tabular}{ccccccccc}
\hline & \multicolumn{9}{c}{ Pre test } & \multicolumn{4}{c}{ Post test } \\
\cline { 2 - 10 } & $\begin{array}{c}\text { Jumlah } \\
\text { Benar }\end{array}$ & $\%$ & $\begin{array}{c}\text { Jumlah } \\
\text { Salah }\end{array}$ & \% & $\begin{array}{c}\text { Jumlah } \\
\text { Benar }\end{array}$ & \% & $\begin{array}{c}\text { Jumlah } \\
\text { Salah }\end{array}$ & \% \\
\hline 1 & 9 & 30 & 21 & 70 & 29 & 96,7 & 1 & 3,3 \\
2 & 24 & 80 & 6 & 20 & 30 & 100 & 0 & 0 \\
3 & 8 & 26,7 & 22 & 73,3 & 29 & 96,7 & 1 & 3,3 \\
4 & 27 & 90 & 3 & 10 & 30 & 100 & 0 & 0 \\
5 & 27 & 90 & 3 & 10 & 30 & 100 & 0 & 0 \\
6 & 27 & 90 & 3 & 10 & 29 & 96,7 & 1 & 3,3 \\
7 & 27 & 90 & 3 & 10 & 30 & 100 & 0 & 0 \\
8 & 28 & 93,3 & 2 & 6,7 & 30 & 100 & 0 & 0 \\
9 & 27 & 90 & 3 & 10 & 30 & 100 & 0 & 0 \\
10 & 28 & 93,3 & 2 & 6,7 & 30 & 100 & 0 & 0 \\
11 & 27 & 90 & 3 & 10 & 30 & 100 & 0 & 0 \\
12 & 27 & 90 & 3 & 10 & 30 & 100 & 0 & 0 \\
13 & 26 & 86,7 & 4 & 13,3 & 30 & 100 & 0 & 0 \\
14 & 28 & 93,3 & 2 & 6,7 & 30 & 100 & 0 & 0 \\
15 & 4 & 13,3 & 26 & 86,7 & 30 & 100 & 0 & 0 \\
16 & 15 & 50 & 15 & 50 & 30 & 100 & 0 & 0 \\
17 & 29 & 96,7 & 1 & 3,3 & 30 & 100 & 0 & 0 \\
18 & 28 & 93,3 & 2 & 6,7 & 29 & 96,7 & 1 & 3,3 \\
19 & 17 & 56,7 & 13 & 43,3 & 30 & 100 & 0 & 0 \\
20 & 24 & 80 & 6 & 20 & 30 & 100 & 0 & 0 \\
\hline
\end{tabular}



Tabel 8. Hasil analisis uji Wilcoxon

\begin{tabular}{|ll|c|}
\hline & & $\mathrm{N}$ \\
\cline { 2 - 3 } Tingkat pengetahuan \\
Post-test dan Pre-test & Negatif & $0^{\mathrm{a}}$ \\
\cline { 2 - 3 } & Positif & $30^{\mathrm{b}}$ \\
\cline { 2 - 3 } & Ties & $0^{\mathrm{c}}$ \\
\cline { 2 - 3 } & Total & 30 \\
\hline
\end{tabular}

Tabel 9. Hasil data statistik uji Wilcoxon

\begin{tabular}{lcc}
\hline $\begin{array}{c}\text { Tingkat } \\
\text { Pengetahuan }\end{array}$ & $\mathrm{N}$ & $p$ \\
\hline Pre - test & 30 & 0,000 \\
\hline Post - test & 30 & 0,000 \\
\hline
\end{tabular}




\section{MEDIA FARMASI}

POLITEKNIK KESEHATAN MAKASSAR

Penasehat

Penanggung Jawab

Dewan Redaksi

Ketua

Anggota

Mitra Bestari

Alamat Redaksi
: Direktur Politeknik Kesehatan Kemenkes Makassar

: Ketua Jurusan Farmasi Politeknik Kesehatan

Kemenkes Makassar

: $\quad$ Santi Sinala, S,Si, M.Si, Apt

: Hendra Stevani, S.Si, M.Kes, Apt

Sisilia Teresia Rosmala Dewi, S.Si, M.Kes, Apt

Muli Sukmawaty, S.Farm, Apt

Muhammad Riswan, S.Kom

: $\quad$ Dr. Islamudin Ahmad, M.Si,Apt (Universitas Mulawarman)

DR. Rusli, Sp.FRS, Apt

DR. Hj. Nurisyah, M.Si, Apt (Poltekkes Makassar)

DR. Sesilia Rante Pakadang, M.Si, Apt (Poltekkes Makassar)

DR. H. Asyhari Asyikin, S.Farm, M.Kes (Poltekkes Makassar)

: Jurusan Farmasi

Politeknik Kesehatan Kementerian Kesehatan Makassar

J1. Baji Gau No.10 Makassar

Telp. 0411-854021, 830883 Fax. 0411-830883

Kode pos 90134

Website :

http://journal.poltekkes-mks.ac.id/ojs2/index.php/mediafarmasi/index 


\section{EDITORIAL}

Pembaca yang budiman, ucapan syukur Alhamdulillah kami panjatkan ke hadirat Tuhan Yang Maha Kuasa karena berkat rahmat dan anugerahNya sehingga penerbitan Vol. XIV No.2, Oktober 2018 MEDIA FARMASI POLITEKNIK KESEHATAN MAKASSAR dapat terlaksana dan telah mendapat legalitas sebagai media resmi dari Lembaga Ilmu Pengetahuan Indonesia (LIPI) dengan nomor penerbitan pISSN No. 0216-2083 dan e-ISSN No. 2622-0962.

Media Farmasi Politeknik Kesehatan Makassar merupakan suatu wadah dalam menampung aspirasi ilmiah sehingga dapat menggugah motivasi dan inovasi dari dosen di lingkup Jurusan Farmasi Politeknik Kesehatan Makassar serta artikel dari simpatisan untuk melakukan kajian ilmiah.

Media Farmasi Politeknik Kesehatan Makassar diterbitkan 2 kali dalam setahun yaitu pada bulan April dan Oktober. Sebagai majalah ilmiah, Media Farmasi mengembangkan misi dalam memajukan ilmu pengetahuan dan teknologi kesehatan khususnya di bidang farmasi

Akhirnya redaksi sangat berharap bahwa semua artikel yang disajikan dalam edisi ini dapat memberi apresiasi keilmuan di bidang kesehatan bagi kita semua. Oleh karena itu kritikan dan saran sangat kami harapkan demi kesempurnaan edisi-edisi selanjutnya.

Selamat membaca

Makassar, Oktober 2018

Redaksi 




Pengaruh Pemberian Ekstrak Etanol Daun Afrika (Vernonia amygdalina

Del.) terhadap Kadar Asam Urat Darah Mencit Jantan (Mus musculus)

Jumain, Asmawati, Rini Karnita

Efektivitas Pemberian Rebusan Daun Pandan Wangi (Pandanus

Amaryllifolius Roxb.) terhadap Penurunan Kadar Glukosa Darah

Mencit (Mus musculus)

Amran Nur, Desi Reski Fajar, Musdalifah

Uji Efek Analgetik Infusa Jahe (Zingiber officinale Roscoe) terhadap Hewan Uji Mencit Jantan (Mus musculus)

Sisilia T. Rosmala Dewi, Hiany Salim.

Pengaruh Usia dan Tingkat Pendidikan terhadap Pemahaman Pasien

Setelah Pelayanan Informasi Obat di Puskesmas Makale Kabupaten

Tana Toraja Tahun 2018

Estherina Allo Payung, Septyani Mambela

Uji Daya Hambat Antibiotika Terhadap Bakteri Penyebab Infeksi

Saluran Kemih Di Rumah Sakit Salewangang Maros

Andi Dian Aulia Saudi, Rusdy

Uji Aktivitas Ekstrak Buah Pare (Momordica charantia L) terhadap Pertumbuhan Propionibacterium acnes

Dwi Rachmawaty Daswi, Asmawati

Analisis Kandungan Merkuri (Hg) pada Sediaan Krim Pemutih yang Beredar di Pasaran Kota Makassar dengan Menggunakan Metode Spektrofotometri Serapan Atom

Dedy Ma'ruf, Andi Asmawati, Ririn Muliana

Penentuan Total Polifenol Ekstrak Etanol Kulit Kecapi (Sandoricum koetjape) dari Lamasi Kabupaten Luwu

Santi Sinala, Minati, Alfrida Monica Salasa

Uji Potensi Antimikroba Hasil Fraksinasi Ekstrak Daun Kecombrang (Etlingera elatior) terhadap Candida albicans Penyebab Keputihan Pada Ibu Hamil

St. Ratnah, Alfrida Monica Salasa, H. Ismail Ibrahim 
Efek Konseling terhadap Tingkat Pengetahuan Ibu pada Terapi

Diare Balita

Khaerani, Surya Ningsi, Andi Try Resti Fauziah Sahib

Uji Daya Hambat Daun Tammate (Lannea coromandelica) terhadap

Bakteri Propionibacterium acnes dan Escherichia coli

Nurlaela, Abd.Karim, Taufiq Dalming

Efektivitas Ekstrak Air Buah Belimbing Wuluh (Averrhoa bilimbi)

Terhadap Pertumbuhan Propionibacterium acnes

Arisanty, Rara Puspa Dewi

Aktivitas Perasan Biji Pinang (Areca catechu L.) terhadap Pertumbuhan

Streptococcus mutans

Ikke Nurjanna, Hendra Stevani, Ratnasari Dewi

Evaluasi Tingkat Kepuasaan Pasien terhadap Pelayanan Kefarmasin di Depo IGD

Rumah Sakit TK II Pelamonia Makassar

Rahmawati, Desi Reski Fajar, Ira Widya Sari

78

Analisis Lama Waktu Tunggu Pelayanan Resep di Apotek BPJS

Rawat Jalan Rumah Sakit Pelamonia

Veronika Dampung, Ita Purnama Sari, Citra Rahayu, Rusli 